\title{
Brucella Prevalent Strains Circulating in Egypt during 2020-2021: Bacteriological and Molecular Study
}

\author{
Hosein H.I. ${ }^{*}$ - Mahmoud E.R. Hamdy ${ }^{2}$ - Ahmed M.A. Zaitoun ${ }^{3}$ - Ahmed M. \\ Menshawy' ${ }^{1}$ Sherin R. Rouby' ${ }^{1}$ Bahaa S. Madkour ${ }^{4}$ Amira M. Mazeed ${ }^{2}$ - Aml M. \\ Abdel-Ra'ouf ${ }^{4}$
}

Received: 02 August 2021 | Accepted: 24 August 2021 I Published online: 28 August 2021

\footnotetext{
${ }^{1}$ Department of Veterinary Medicine, Faculty of Veterinary Medicine, Beni-Suef University, Beni-Suef 62511, Egypt.

${ }^{2}$ Department of Brucella Researches, Animal Health Research Institute, (AHRI) Dokki, Giza, Egypt.

${ }^{3}$ Department of Animal Medicine, Faculty of Veterinary Medicine, Assiut University, Assiut, Egypt.

${ }^{4}$ Department of Animal Medicine, Faculty of Veterinary Medicine, Aswan University, Aswan Egypt.
}

\section{Correspondence}

Hosein HI, Department of Veterinary Medicine, Faculty of Veterinary Medicine, Beni-Suef University, Beni-Suef 62511, Egypt.

Email:

hoseinabdalaal2014@yahoo.com

\begin{abstract}
Brucellosis is a major constraint to livestock production that still enzootic in livestock in many developing countries including Egypt. This study was conducted with the general objective of establishing the bacteriological status of bovine brucellosis in 15 governorates in Egypt during 2020-2021 to determine the circulating Brucella species on bacteriological and molecular basis. Clinical samples collected included milk or udder secretions, vaginal discharges, fetal membranes and stomach contents of aborted fetuses from dairy cows with history of brucellosis. In addition, lymph nodes (retropharyngeal, prescapular, prefemoral, internal iliac and supramammary) from carcasses of serologically positive animals were obtained from different localities for isolation and identification of Brucella organisms. A total of 136 Brucella isolates were recovered from cattle in different governorates, Egypt. These include, 107 isolates of Brucella melitensis biovar 3 identified on bacteriological and molecular basis from Aswan, Beheira, Beni Suef, Dakahlia, Damietta, Fayoum, Gharbia, Giza, Ismailia, Kafr El-Sheikh, Luxor, Monufia, Port Said, Qalyubia and Sharqia governorates. On the other hand, 29 Brucella abortus biovar 1 isolates were recovered from cattle from Beni Suef, Dakahlia, Damietta, Kafr El-Sheikh, Monufia, Port Said and Sharqia governorates. Molecular identification using primer sequences targeting IS711 gene confirmed Brucella on genus level. Multiplex PCR has amplified four fragments of $450 \mathrm{bp}, 587 \mathrm{bp}, 1071 \mathrm{bp}$, and1682 bp characteristic for B. melitensis biovar 3, and three fragments of $450 \mathrm{bp}, 587 \mathrm{bp}$, and $1682 \mathrm{bp}$ for $B$. abortus biovar 1 . The identification of Brucella spp. in different farm animals of 15 Egyptian governorates highlights the dynamics and role of cattle in dissemination of Brucella infection all over the country. The obtained results indicate that the actual Brucellosis status during the years 2020 and 2021 refers to that $B$. melitensis biovar 3 and $B$. abortus biovar 1 are the prevalent types circulating in different Egyptian governorates.
\end{abstract}

Keywords Brucellosis, Bacteriology, Egypt, Molecular typing 


\section{Introduction}

Brucellosis is a major constraint to livestock production that still enzootic in livestock in many developing countries including Egypt (Pappas et al. 2006; Hegazy et al. 2011; Eltholth et al. 2016). The disease affects animals and causes reproductive disorders, including abortion, retained placenta, stillbirth, orchitis, decreased milk yield and costs for breeding improvements (Saeed et al. 2019). The prevalence of human brucellosis in Egypt has been reported as high as $8 \%$ in high-risk populations (Samaha et al. 2009). Humans get infected via the ingestion of contaminated raw milk, unpasteurized dairy products, handling of infected animals, animal discharges (Godfroid et al. 2013; Tuon et al. 2017). Brucella species are Gram negative, non-motile, nonsporulating, microaerophilic intracellular pathogens that actively multiply inside professional and nonprofessional phagocytes (Pizarro-Cerda et al. 2000; Arellano-Reynoso et al. 2004; Celli, et al. 2003). Brucella is capable to persist inside non-activated macrophages that are eventually in charge for its clearance (Baldwin and Winter 1994); Gorvel and Moreno (2002); Halling (2002). The Brucella genus includes 12 recognized species with varying host preferences, pathogenicity, and epidemiology (OIE, Brucellosis 2019).

The identification of the Brucella isolates recovered from milk, aborted material, lymph nodes, and other tissue specimens of slaughtered animals is carried out through typing of the causative microorganism on bacteriological and molecular basis, (Moreno and Moriyon 2001; Ulu-Kilic et al. 2013; OIE 2019).

In cattle, the susceptibility varies according to the route of infection and dose of exposure and gestation stage with adult pregnant cows are more susceptible to infection (Palmer et al. 1996). This susceptibility is thought to attribute to the concentration of the sugar erythritol in the gravid bovine uterus as reported by Schurig et al. (1991). Shedding of Brucellae occurs through milk, and aborted material (Corbel 1997) with the abomasal content of the aborted fetus as one of the preferred samples for Brucella isolation. Primarily, Brucella abortus causes infection in cattle and buffaloes, Brucella melitensis in sheep and goats, and Brucella suis in pigs. However, cross-species infection between different animal species is also possible (Saeed et al. 2019).

In Egypt, B. abortus, B. suis and B. melitensis strains were isolated from livestock having high levels of phylogenetic variability within each species (Menshawy et al. 2014). Culture and biochemical typing remain the "gold standard" for the diagnosis of Brucella infection (Alton et al. 1988; Vicente et al. 2014); these include $\mathrm{CO}_{2}$ requirement, $\mathrm{H}_{2} \mathrm{~S}$ production, dye sensitivity, urease, oxidase, and catalase tests.

This study was conducted with the general objective of establishing the bacteriological status of bovine brucellosis in 15 governorates in Egypt to determine the circulating Brucella species on bacteriological and molecular basis.

\section{Material and Methods}

\subsection{Study areas}

The study was carried out in 15 Egyptian governorates representing Upper and Lower Egypt, Table (1) and Fig. (1), and the main objective was to identify Brucella spp. circulating in Egypt.

\subsection{Ethical approval}

This study was carried out under strict accordance with the guidelines of ethical committees of the Faculty of Veterinary Medicine, Beni-Suef University and Animal Health Research Institute, Dokki, Egypt.

\subsection{Samples for bacteriological examination}

During January 2020 to March 2021, clinical samples were collected from cattle dairy farms in 15 governorates by the veterinary authorities of the General Organization of Veterinary Services (GOVS) and submitted to the department of Brucellosis, Animal Health Research Institute, Dokki, Egypt for Brucella isolation. Milk or udder secretions (a pool from all four mammary glands) from dairy cows, vaginal discharges, fetal membranes and stomach contents of aborted fetuses were obtained from different localities. Lymph nodes (retropharyngeal, prescapular, prefemoral, internal iliac and supramammary) from seropositive slaughtered cows were also collected for isolation and identification of Brucella organisms, (Table 1). Animals targeted for bacteriological examination were either Brucella serologically positives sent to abattoir for slaughtering (lymph nodes) or from known Brucella infected dairy farms diagnosed by the (GOVS). Immediately after collection, samples were transported to the laboratory and stored as recommended in the guidelines of OIE (2019). 
The demographic and descriptive epidemiological data related to brucellosis important risk factors; age, pregnancy status, lactation, history of abortion, reproductive problems, Brucella vaccination history, vaccination against other infectious diseases and health and disease conditions) were collected.

The cattle populations from the study areas were not vaccinated against Brucellosis. However, most animals in these herds were vaccinated against other infectious enzootic diseases in Egypt such as Foot and Mouth Disease (FMD), Rift Valley Fever (RVF), and Lumpy Skin Disease (LSD). The common infectious diseases that affected cattle population other than brucellosis during this study included Mastitis, Foot and mouth disease, Lumpy skin diseases and Ephemeral fever.

\subsection{Bacteriological examination}

Milk samples were centrifuged at $6000 \mathrm{~g}$ for $15 \mathrm{~min}$. The obtained cream and sediment were mixed and used for Brucella isolation. Fetal stomach contents were collected from the stomach of an aborted fetus with a sterile Pasteur pipette for Brucella isolation. Milk cream and sediment mixture, vaginal discharges, and stomach contents of aborted fetuses were spread on a solid on tryptose agar medium with selective antibiotic supplement as recommended by Alton et al. (1988); OIE 2019. Tissue specimens (lymph nodes and cotyledons were immersed in alcohol and flamed before being cut in small pieces (Alton et al. 1988). The cut surface of was macerated and rubbed onto the culture plates culture plates. Typically, round, glistening, pinpoint and honey drop-like cultures were stained with Gram and modified ZiehlNeelsen staining (MZN) methods. Subsequent biochemical tests and agglutination with monospecific sera were performed.

\subsection{DNA extraction}

DNA extraction from samples was performed using the QIAamp DNA Mini kit (Qiagen, Germany, $\mathrm{GmbH}$ ) with modifications. Briefly, $200 \mu \mathrm{l}$ of the sample suspension was incubated with $10 \mu \mathrm{l}$ of proteinase $\mathrm{K}$ and $200 \mu \mathrm{l}$ of lysis buffer at $56^{\circ} \mathrm{C}$ for 10 min. After incubation, $200 \mu \mathrm{l}$ of $100 \%$ ethanol was added to the lysate. The sample was then washed and centrifuged following the manufacturer's recommendations. Nucleic acid was eluted with $100 \mu$ of elution buffer provided in the kit.

\subsection{PCR}

The IS711 conventional PCR targeting gene according to Bricker and Halling (1994) was used in this study to detect Brucella DNA in Brucella isolates to the genus Brucella. Multiplex PCR was done at Department of Veterinary Medicine, Beni-Suef University to identify Brucella isolates to the species level. Primer sequences used for conventional and multiplex PCR are listed in Table (2). The cycling conditions were $4 \mathrm{~min}$ at $94^{\circ} \mathrm{C}$ for initial heating, 35 cycles of $45 \mathrm{~s}$ at $94^{\circ} \mathrm{C}, 45 \mathrm{~s}$ at $55^{\circ} \mathrm{C}$ (conventional PCR) $65^{\circ} \mathrm{C}$ (Multiplex PCR) followed by $60 \mathrm{~s}$ at $72^{\circ} \mathrm{C}$, and final extension for $7 \mathrm{~min}$ at $72^{\circ} \mathrm{C}$.

\subsection{Analysis of $P C R$ products}

The products of PCR were separated by electrophoresis on $1 \%$ agarose gel (Applichem, Germany, GmbH) in $1 \mathrm{x}$ TBE buffer at room temperature using gradients of $5 \mathrm{~V} / \mathrm{cm}$. For gel analysis, $15 \mu \mathrm{l}$ of the products was loaded in each gel slot. A gelpilot 100 bp plus DNA Ladder (Qiagen, Germany, GmbH) was used to determine the fragment sizes. The gel was photographed by a gel documentation system (Alpha Innotech, Biometra).

Fig. 1. Areas of study and locations of different governorates from which samples were collected.

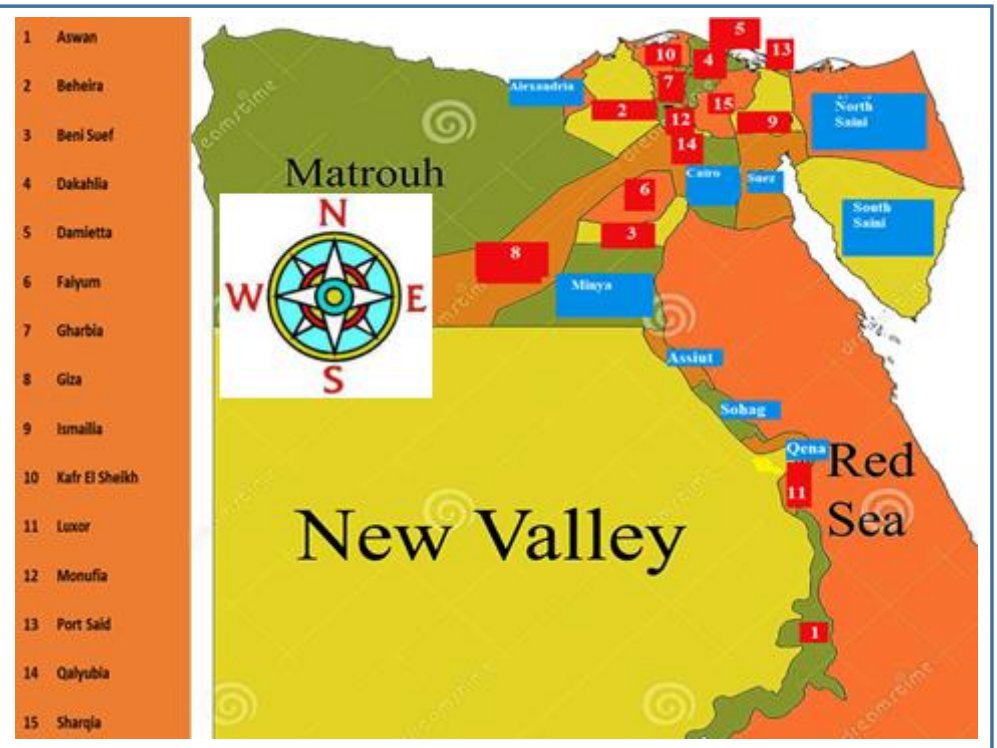


Table 1. Samples collected from different animals from different governorates for bacteriological investigation.

\begin{tabular}{lccccc}
\hline Governorate & Milk & LN & $\begin{array}{c}\text { Vaginal } \\
\text { discharges }\end{array}$ & $\begin{array}{c}\text { Stomach } \\
\text { contents }\end{array}$ & $\begin{array}{c}\text { (F.M.) } \\
\text { Cotyledons }\end{array}$ \\
\hline Aswan & 10 & 2 & 0 & 0 & 0 \\
Beheira & 27 & 0 & 2 & 0 & 2 \\
Beni Suef & 5 & 3 & 0 & 0 & 0 \\
Dakahlia & 3 & 5 & 3 & 2 & 2 \\
Damietta & 7 & 5 & 3 & 2 & 2 \\
Fayoum & 11 & 8 & 0 & 0 & 0 \\
Gharbia & 3 & 7 & 0 & 0 & 0 \\
Giza & 8 & 5 & 1 & 0 & 0 \\
Ismailia & 4 & 12 & 0 & 1 & 1 \\
Kafr El-Sheikh & 6 & 3 & 0 & 0 & 2 \\
Luxor & 2 & 6 & 0 & 1 & 0 \\
Monufia & 12 & 11 & 1 & 1 & 1 \\
Port Said & 4 & 15 & 2 & 0 & 1 \\
Qalyubia & 10 & 13 & 2 & 2 & 2 \\
Sharqia & 16 & 8 & 2 & 11 & 13 \\
\hline Total 271 & 128 & 103 & 16 & & 0 \\
\hline
\end{tabular}

LN. Lymph nodes, FM. Fetal membranes

Table 2. Primer sequences for universal and multiplex PCR.

\begin{tabular}{rrr}
\hline IR1 & Sequence (5'-3') & Amplicon size (bp) \\
IR2 & GGC-GTG-TCT-GCA-TTC-AAC-G & 839 \\
BMEI0535f & GGC-TTG-TCT-GCA-TTC-AAG-G & \multirow{2}{*}{450} \\
BMEI0535r & GCG-CAT-TCT-TCG-GTT-ATG-AA & \multirow{2}{*}{1682} \\
BMEI0998f & CGC-AGG-CGA-AAA-CAG-CTA-TAA & \\
BMEI0997r & ATC-CTA-TTG-CCC-CGA-TAA-GG & 1071 \\
BMEII0843f & GCT-TCG-CAT-TTT-CAC-TGT-AGC & \\
BMEII0844r & TTT-ACA-CAG-GCA-ATC-CAG-CA & 587 \\
BMEII0428f & GCG-TCC-AGT-TGT-TGT-TGA-TG & \\
BMEII0428r & GCC-GCT-ATT-ATG-TGG-ACT-GG & 272 \\
BR0953f & AAT-GAC-TTC-ACG-GTC-GTT-CG & 218 \\
BR0953r & GGA-ACA-CTA-CGC-CAC-CTT-GT & \\
BMEI0752f & GAT-GGA-GCA-AAC-GCT-GAA-G & \\
BMEI0752r & CAG-GCA-AAC-CCT-CAG-AAG-C & \\
\hline
\end{tabular}

\section{Results}

All the isolates showed typical characteristics for the genus Brucella; translucent colonies with a pale honey color when viewed in the daylight and convex and pearly white when viewed from above.

On the basis of microbiological and biochemical characteristics, 107 isolates were typed as Brucella melitensis biovar 3 and 29 as Brucella abortus biovar 1 (Table 3).

Using primer sequences targeting IS711 gene, PCR has amplified the fragment $839 \mathrm{bp}$ (Fig. 2) confirming the presence of Brucella on genus level. On the other hand, Multiplex PCR has amplified five fragments of 218bp, 450bp, 587 bp, 1071 bp, and1682 bp for $B$. melitensis Rev1vaccine strain, four fragment of 450bp, $587 \mathrm{bp}, 1071 \mathrm{bp}$, and $1682 \mathrm{bp}$ for B. melitensis biovar 3, three fragment of $450 \mathrm{bp}, 587 \mathrm{bp}$, and 1682 bp for B. abortus biovar 1(Figure-3).

Distribution of both Brucella melitensis isolates and Brucella abortus isolates among different governorates in Egypt were illustrated in Tables (4, 5). 
Table 3. Result of identification of Brucellae isolated from different samples

\begin{tabular}{lcccc}
\hline Samples & No. of & Brucella culture & Brucella abortus & Brucella melitenisis \\
biovar 1 & Positives & 8 & 47 \\
bilk & 128 & $55(43 \%)$ & 9 & 50 \\
LN & 103 & $59(57.3 \%)$ & 3 & 6 \\
Vaginal discharges & 16 & $9(56 \%)$ & 3 & 2 \\
Stomach contents & 11 & $5(45.5 \%)$ & 6 & 2 \\
(F.M.) Cotyledons & 13 & $8(61.5 \%)$ & 29 & 107 \\
\hline Total & 271 & 136 & 5 & 2 \\
\hline
\end{tabular}

Table 4. Distribution of Brucella melitensis among different governorates in Egypt.

\begin{tabular}{|c|c|c|c|c|c|c|}
\hline Governorate & Milk & LN & $\begin{array}{c}\text { Vaginal } \\
\text { discharges }\end{array}$ & S. contents & $\begin{array}{c}\text { (F.M.) } \\
\text { Cotyledons }\end{array}$ & $\begin{array}{l}\text { No. of } \\
\text { isolates }\end{array}$ \\
\hline Aswan & 3 & 1 & 0 & 0 & 0 & 4 \\
\hline Beheira & 11 & 0 & 0 & 0 & 0 & 11 \\
\hline Beni Suef & 2 & 2 & 0 & 0 & 0 & 4 \\
\hline Dakahlia & 2 & 2 & 0 & 0 & 0 & 4 \\
\hline Damietta & 3 & 3 & 2 & 1 & 1 & 10 \\
\hline Fayoum & 3 & 3 & 0 & 0 & 0 & 6 \\
\hline Gharbia & 1 & 3 & 0 & 0 & 0 & 4 \\
\hline Giza & 2 & 3 & 0 & 0 & 0 & 5 \\
\hline Ismailia & 2 & 7 & 0 & 0 & 0 & 9 \\
\hline Kafr El-Sheikh & 2 & 1 & 0 & 0 & 0 & 3 \\
\hline Luxor & 1 & 2 & 0 & 0 & 0 & 3 \\
\hline Monufia & 5 & 6 & 1 & 0 & 0 & 12 \\
\hline Port Said & 2 & 4 & 1 & 0 & 0 & 7 \\
\hline Qalyubia & 4 & 7 & 2 & 0 & 0 & 13 \\
\hline Sharqia & 4 & 6 & 0 & 1 & 1 & 12 \\
\hline Total & 47 & 50 & 6 & 2 & 2 & 107 \\
\hline
\end{tabular}

Table 5. Distribution of Brucella abortus isolates among different governorates in Egypt.

\begin{tabular}{|c|c|c|c|c|c|c|}
\hline Governorate & Milk & LN & $\begin{array}{c}\text { Vaginal } \\
\text { discharges }\end{array}$ & S. contents & $\begin{array}{c}\text { (F.M.) } \\
\text { Cotyledons }\end{array}$ & $\begin{array}{c}\text { No. of } \\
\text { isolates }\end{array}$ \\
\hline Aswan & 0 & 0 & 0 & 0 & 0 & 0 \\
\hline Beheira & 0 & 0 & 0 & 0 & 0 & 0 \\
\hline Beni Suef & 0 & 1 & 0 & 0 & 0 & 1 \\
\hline Dakahlia & 1 & 2 & 0 & 0 & 0 & 3 \\
\hline Damietta & 2 & 1 & 1 & 1 & 1 & 6 \\
\hline Fayoum & 0 & 0 & 0 & 0 & 0 & 0 \\
\hline Gharbia & 0 & 0 & 0 & 0 & 0 & 0 \\
\hline Giza & 0 & 0 & 0 & 0 & 0 & 0 \\
\hline Ismailia & 0 & 0 & 0 & 0 & 0 & 0 \\
\hline Kafr El-Sheikh & 1 & 1 & 0 & 1 & 1 & 4 \\
\hline Luxor & 0 & 0 & 0 & 0 & 0 & 0 \\
\hline Monufia & 2 & 2 & 0 & 0 & 1 & 5 \\
\hline Port Said & 2 & 1 & 1 & 0 & 1 & 5 \\
\hline Qalyubia & 0 & 0 & 0 & 0 & 0 & 0 \\
\hline Sharqia & 0 & 1 & 1 & 1 & 2 & 5 \\
\hline Total & 8 & 9 & 3 & 3 & 6 & 29 \\
\hline
\end{tabular}


Table 6. Characterization of Brucella isolates at the species and biovar levels.

\begin{tabular}{|c|c|c|c|c|c|c|c|c|c|c|c|c|c|c|}
\hline \multirow{3}{*}{ Br. isolates } & \multirow{3}{*}{$\mathrm{CO}_{2}$} & \multirow{3}{*}{$\mathrm{H}_{2} \mathrm{~S}$} & \multirow{3}{*}{ Urease } & \multicolumn{4}{|c|}{ Growth on dyes } & \multicolumn{2}{|c|}{$\begin{array}{c}\text { Lysis by Tb } \\
\text { phage }\end{array}$} & \multirow{3}{*}{$\begin{array}{c}\begin{array}{c}\text { Lysis } \\
\text { by Iz1 }\end{array} \\
\text { RTD }\end{array}$} & \multicolumn{3}{|c|}{$\begin{array}{c}\text { Monospecific } \\
\text { sera }\end{array}$} & \multirow{3}{*}{ Conclusion } \\
\hline & & & & \multicolumn{2}{|c|}{ Thionin } & \multicolumn{2}{|c|}{ Fuchsin } & \multirow[b]{2}{*}{ RTD } & \multirow{2}{*}{$\begin{array}{l}\text { RTD } \\
10^{4}\end{array}$} & & \multirow[b]{2}{*}{ A } & \multirow[b]{2}{*}{$\mathbf{M}$} & \multirow[b]{2}{*}{$\mathbf{R}$} & \\
\hline & & & & a & b & $a$ & $b$ & & & & & & & \\
\hline $\begin{array}{c}107 \text { Brucella } \\
\text { isolates }\end{array}$ & - & - & $\begin{array}{c}+ \text { in } 20 \\
\text { hrs }\end{array}$ & + & + & + & + & - & - & + & + & + & - & $\begin{array}{c}\text { B. melitensis } \\
3\end{array}$ \\
\hline $\begin{array}{l}29 \text { Brucella } \\
\text { isolates }\end{array}$ & - & + & $\begin{array}{c}+ \text { in } 2 \\
\text { hrs }\end{array}$ & - & - & + & + & + & + & + & + & - & - & B. abortus 1 \\
\hline $\begin{array}{c}\text { B. melitensis } \\
\text { Ether }\end{array}$ & - & - & $\begin{array}{c}+ \text { in 18- } \\
24 \mathrm{hr} .\end{array}$ & + & + & + & + & - & - & + & + & + & - & $\begin{array}{c}\text { B. melitensis } \\
3\end{array}$ \\
\hline $\begin{array}{c}\text { B. abortus } \\
544\end{array}$ & - & + & $\begin{array}{c}+ \text { in } 2 \\
\text { hrs }\end{array}$ & - & - & + & + & + & + & + & + & - & - & B. abortus 1 \\
\hline B. Suis 1330 & - & +++ & $\begin{array}{l}++ \text { in }< \\
15 \mathrm{~min} .\end{array}$ & + & + & - & - & - & + & + & + & - & - & B. Suis 1 \\
\hline
\end{tabular}

RTD: routine test dilution, Tp: Tbilisi (Tb), Iz1: Izatnagar, a: 1:50000, A: anti Brucella abortus, M: anti Brucella melitensis, R: rough brucella antiserum.

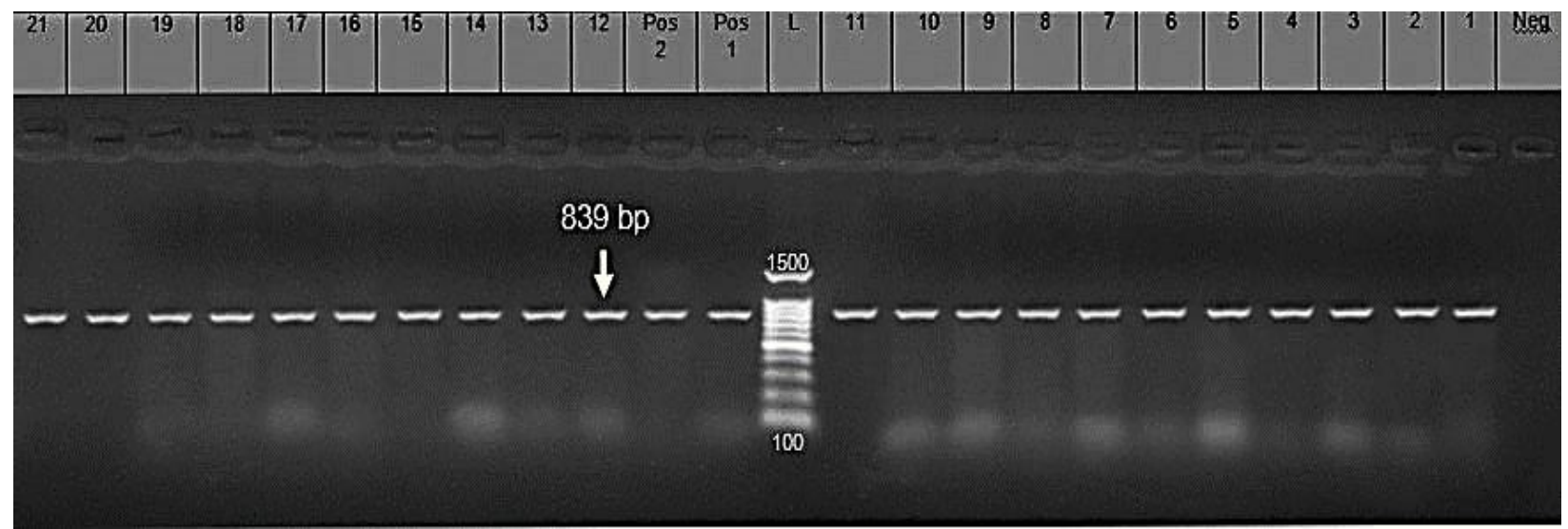

Fig. 2. Detection of IS711 gene specific for genus Brucella by conventional polymerase chain reaction (PCR). Lane L: $100 \mathrm{bp}$ marker, Lane (1P): B. melitensis reference strain Ether, Lane3: (2P). B. abortus 544 reference strain, lane3 (N): control negative, Lanes (1-11) B. melitensis cultures, Lane (12-21) B. abortus cultures.

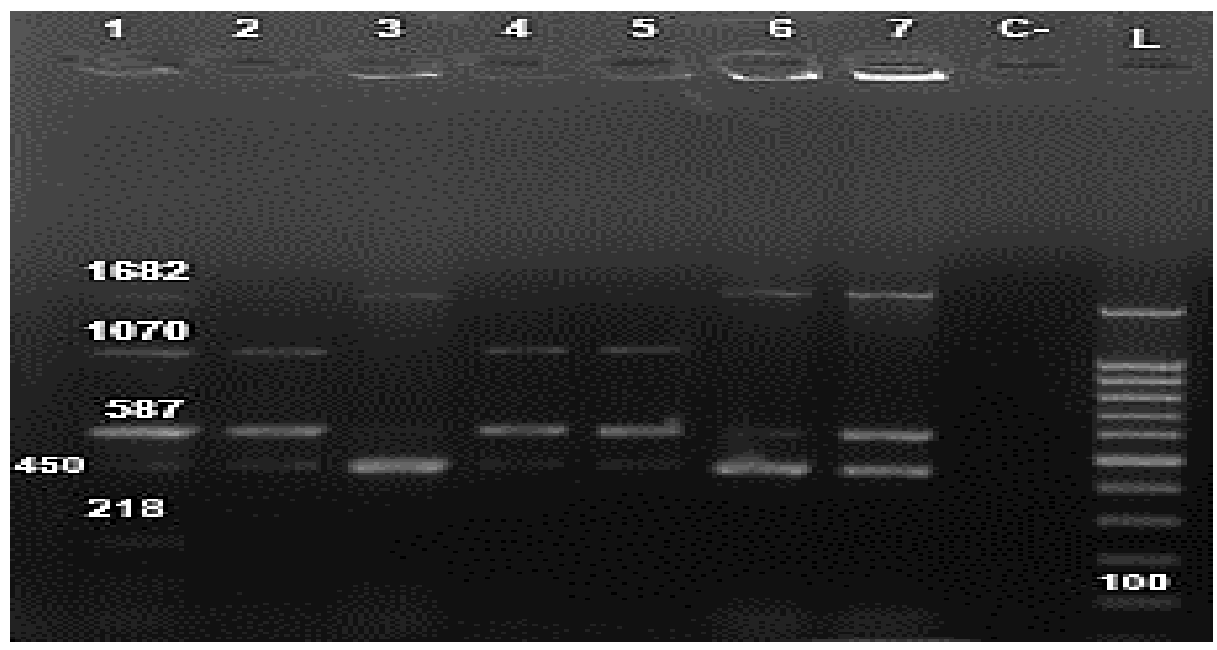

Fig. 3. Multiplex PCR of Brucella isolates. Lane (1): $B$. melitensis Rev1 vaccine strain, Lane (2) $B$. melitensis reference strain Ether, Lane (3) B. abortus 544 reference strain, Lanes (4,5): B. melitensis cultures control negative, Lanes (6,7) B. abortus cultures, Lane 8 (C-): control negative, Lane L: 100 bp marker. 


\section{Discussion}

The identification of Brucella spp. in farm animals of 15 Egyptian governorates highlights the role of cattle in dissemination of Brucella infection all over the country. A total of 136 Brucella isolates were recovered from cattle in different governorates, Egypt. These include, 107 isolates of Brucella melitensis biovar 3 recovered and identified on bacteriological and molecular basis from cattle from Aswan, Beheira, Beni Suef, Dakahlia, Damietta, Fayoum, Gharbia, Giza, Ismailia, Kafr El-Sheikh, luxor, Monufia, Port Said, Qalyubia and Sharqia governorates, Table (4). On the other hand, 29 Brucella abortus biovar 1 isolates were recovered from cattle from Beni Suef, Dakahlia, Damietta, Kafr El-Sheikh, Monufia, Port Said and Sharqia governorates, Table (5). Several previous studies described the prevailing of Brucella Spp. infection among cattle in Egypt (Khoudair and Sarfenaze 2007; Rehab 2011; Menshawy et al. 2014; Hosein et al. 2017; Hosein et al. 2018; Khan et al. 2020). Brucella melitensis biovar 3 was previously considered as the prevalent type in Egypt (Salem and Hosin 1990). Originally, Brucella melitensis affects mainly sheep and goats. The isolation of $B$. melitensis from cattle and buffaloes in this study may be attributed to mixed farming of large and small ruminants as previously explained by Wareth et al. (2014); Hosein et al. (2016). Cross-species infections frequently occur when different species are raised together. Brucella melitensis was isolated from cattle, buffalo, sheep, goat, (Samaha et al. 2008). Brucella melitensis cross-infection has been reported in southern Europe (Verger et al. 1989) and in the Middle East (Samaha et al. 2008). In contrast, Brucella abortus was isolated from cattle, buffalo and camel in Egypt (Refai 2002; Hamdy and Amin 2002; Menshawy et al. 2014).

The isolation and typing of Brucella species from clinical samples is considered the gold standard diagnostic method for brucellosis (Bricker 2002; Al Dahouk et al. 2003) as essential tools for the confirmation of Brucella infection and the epidemiological evaluation of the herd as well as trace back of the sources of infection. The PCR assays were capable to confirm the identification of isolated Brucella spp. Using primer sequences targeting IS711 gene, PCR has amplified the fragment 839 bp (Fig. 2) confirming the presence of Brucella on genus level. On the other hand, Multiplex PCR has amplified four fragments of $450 \mathrm{bp}, 587 \mathrm{bp}, 1071 \mathrm{bp}$, and1682 bp characteristic for $B$. melitensis biovar 3, and three fragments of $450 \mathrm{bp}, 587 \mathrm{bp}$, and $1682 \mathrm{bp}$ for $B$. abortus biovar 1 (Fig. 3).

Brucella was isolated from 8 retained fetal membranes out of $13(\mathbf{6 1 . 5 \% )}$. Such high rate of Brucella isolation may be attributed to the number of organisms that tend to be very high in the placental cotyledons as reported by Pinto da Silva et al. (2012). On the other hand, lower rate of Brucella isolation from 55 milk samples out of 128 (43\%), may be due to several limiting factors such as the fastidious nature of the organism and the low number of viable organisms as reported by Alton et al. (1988). Contamination of milk is especially considered as complicating factor for Brucella isolation due to the fastidious nature of Brucella organisms (Alton et al. 1988; Seleem et al. 2010).

Fetal stomach contents and vaginal secretions are among the samples of choice for Brucella isolation (Alton et al. 1975). In this study, Brucellae were isolated from 5 out $11(\mathbf{4 5 . 5 \%})$ stomach contents of aborted calves and 9 out of $16(\mathbf{5 6 \%})$ vaginal discharges of aborted cows. These findings are attributed to the fact that Brucellae propagate in the gravid uterus, amniotic fluid and fetal membranes of pregnant cows in large numbers as predilection seats due to erythritol affinity as reported by Poester et al. (2013). Such preferential multiplication is related to the ability of the genus Brucella to induce abortions in ruminants (Yaeger and Holler 2007).

Brucella was isolated from lymph nodes (retropharyngial, prescapular, prefemoral, internal iliac and supramammary) from carcasses of 59 out of $103(57.3 \%)$ serologically positive animals submitted to abattoirs by the Egyptian veterinary authorities. Although culling of these infected animals is the official policy adopted for control of brucellosis in Egypt, however, many of infected animals all over the country are actually sold in animal's markets with movement of animals from area to area. Interestingly, these infected animals are symptomless and may remain carriers shedding Brucellae into the environment. This results in spread of Brucella infection among different governorates as proved in this study.

It is important to mention that eradication of brucellosis is only possible when positive animals are culled associated with prohibition of movement of Brucella-positive animals and additionally, application of biosecurity practices as well as fair 
compensation policy for owners. (Hosein et al. 2018; Musallam et al. 2019).

\section{Conclusion}

Brucellosis is still a major constraint to livestock production in Egypt. Continuous isolation and typing of Brucella isolates on both bacteriological and molecular bases represent the essential operation toward epidemiological evaluation of Brucella herd infection status and tracing back the sources of infection. The actual Brucellosis status during the years 2020 and 2021 refers to that Brucella melitensis biovar 3 and Brucella abortus biovar 1 are the prevalent types circulating in different Egyptian governorates.

\section{Conflict of interest}

The authors declare no conflict of interest.

\section{References}

Al Dahouk S, Tomaso H, Nockler K, Neubauer H, Frangoulis D (2003). Laboratory-based diagnosis of brucellosis - A review of literature. Part I, techniques for direct detection and identification of Brucella sp. Clinical lab., 49: 487-505.

Alton GG, Jones LM, Angus RD, Verger JM (1988). Techniques for the Brucellosis laboratory. Institute National De La Recherche Agronomique; Paris, France.

Alton GG, Jones LM, Pietz DE, (1975). Laboratory techniques in Brucellosis, WHO monograph Series, 55. Geneva, Switzerland: WHO, 188.

Arellano-Reynoso B, Diaz-Aparicio E, Leal-Hernandez M, Hernandez L, Gorvel JP (2004). Intracellular trafficking study of RB51 B. abortus vaccinal strain isolated from cow's milk. Vet Microbiol., 98: 307-12.

Baldwin CL, Winter AJ (1994). Macrophages and Brucella. Immunol Ser., 60:363-80.

Bricker BJ, Halling SM (1994). Differentiation of Brucella abortus bv. 1, 2, and 4, Brucella melitensis, Brucella ovis, and Brucella suis bv. 1 by pcr. J Clin Microbiol., 32: 2660-2666.

Bricker BJ (2002). Diagnostic strategies used for the identification of Brucella. Vet Microbiol., 90,: 433-434.

Celli J, de Chastellier C, Franchini DM, Pizarro-Cerda J, Moreno E, Gorvel JP (2003). Brucella evades macrophage killing via VirB-dependent sustained interactions with the endoplasmic reticulum. J Exp Med., 198: 545-56.

Corbel MJ (1997). Brucellosis: an overview. Emerg Infect Dis., 3: 213-21.

Eltholth MM, Hegazy YM, El-Tras WF, Rushton J, Bruce M (2016).Temporal analysis and costs of ruminant Brucellosis control programme in Egypt between 1999 and 2011. Transbound. Emerg. Dis., 64: 1191-1199. http://dx.doi.org/10.1111/tbed.12491.

Godfroid J, Al Dahouk S, Pappas G, Roth F, Matope G, Muma J, Marcotty T, Pfeiffer D, Skjerve EA (2013). "one health" surveillance and control of brucellosis in developing countries: Moving away from improvisation. Comp Immunol Microbiol Infect Dis., 36: 241-248.

Gorvel JP, Moreno E (2002). Brucella intracellular life: from invasion to intracellular replication. Vet Microbiol., 90: 281-9.

Halling SM (2002). Paradigm shifts in vaccine development: lessons learned about antigenicity, pathogenicity and virulence of Brucellae. Vet Microbiol., 90: 545-52.

Hamdy MER, Amin AS (2002). Detection of Brucella species in the milk of infected cattle, sheep, goats and camels by PCR. Vet J 163:299-305

Hegazy YM, Molina-Flores B, Shafik H, Ridler A, Guitian F, Guitian J (2011). Ruminant brucellosis in Upper Egypt (2005-2008) Prev Vet Med., 101: 173-181.

http://dx.doi.org/10.1016/j.prevetmed.2011.05.007.

Hosein HI, Rouby S, Menshawy A, Ghazy N (2016). Seroprevalence of camel brucellosis and molecular characterization of Brucella melitensis recovered from dromedary camels in Egypt. Res J Vet Pract., 4(1): 1724.

Hosein HI, Zaki HM, Safwat NM, Menshawy AMS, Rouby S, Mahrous A, Madkour BE (2018). Evaluation of the general organization of veterinary services control program of animal brucellosis in Egypt: An outbreak investigation of brucellosis in buffalo, Vet World, 11(6): 748-757.

Hosein HI, Rouby SR, Menshawy A, AbdAl-Ghany AE (2017). Sensitivity and specificity of the commonly used diagnostic procedures of bovine brucellosis. Vet Sci: Res and Reviews, 3(3): 45-52.

Khan AU, Melzer F, Hendam A, Sayour AE, Khan I, Elschner MC, Younus $M$, Ehtisham-ul-Haque $S$, Waheed U, Farooq M, Ali S, Neubauer H and ElAdawy H (2020). Seroprevalence and molecular identification of Brucella spp. in Bovines in Pakistaninvestigating association with risk factors using machine learning. Front Vet Sci., 7: 594498.

Khoudair RM, Sarfenaze SA (2007). Bacteriological, serological and pathological studies in buffaloes naturally infected with brucellosis. Egy J Comp Path Clinic Path., 20(1): 309-332.

Menshawy A, Perez-Sancho M, GarciaSeco T, Hosein HI, Garcia N, Martinez I, Sayour AE, Goyache J, Azzam RAA, Dominguez L (2014). Assessment of genetic diversity of zoonotic Brucella spp. recovered from livestock in Egypt using multiple locus VNTR analysis. BioMed res int., 1-7. 
Moreno E, Moriyon I (2001). The Genus Brucella. In: Dworkin M, editor. The Procaryotes: An evolving microbiological resource for the microbiological community. 3. New York, NY: Springer. 315-457.

Musallam I, Ndour AP, Yempabou D, Ngong CC, Dzousse MF, Mouiche-Mouliom MM, et al. (2019). Brucellosis in dairy herds: a public health concern in the milk supply chains of West and Central Africa. Acta Trop., 197: 105042.

OIE (2019). Brucellosis (Brucella abortus, B. melitensis and $B$. suis) (infection with B. abortus, B. melitensis and $B$. suis) Manual of diagnostic tests and vaccines for terrestrial animals. Paris: 355-98.

Palmer MV, Cheville NF, Jensen AE (1996). Experimental infection of pregnant cattle with the vaccine candidate Brucella abortus strain RB51:

Pappas G, Papadimitriou P, Akritidis N, Christou L, Tsianos EV (2006). The new global map of human brucellosis. Lancet Infect Dis., 6: 91-99.

Pinto da Silva Mol, Sílvia de Araújo França, Tatiane Alves da Paixão, Renato Lima Santos R bras (2012). Laboratorial diagnosis of animal brucellosis Juliana $\mathrm{Ci}$. Vet., 19(3): 117-126.

Pizarro-Cerda J, Moreno E, Gorvel JP (2000). Invasion and intracellular trafficking of Brucella abortus in nonphagocytic cells. Microbes Infect., 2: 829-35.

Poester FP, Samartino LE, Santos RL. (2013). Pathogenesis and pathobiology of brucellosis in livestock Rev Sci Tech., 32: 105-15.

Refai M (2002). Incidence and control of brucellosis in the Near East region. Vet Microbiol., 90:81-110 12.

Rehab (2011). Epidemiological characterization of Brucella strains in Egypt, PhD thesis, faculty of veterinary medicine, infectious diseases Beni-Suef University, Egypt.

Saeed U, Ali S, Khan TM, El-Adawy H, Melzer F, Khan AU, et al. (2019). Seroepidemiology and the molecular detection of animal brucellosis in Punjab, Pakistan. Microorganisms, 7(10): 449.

Salem AA, Hosein HI (1990). Brucella strains prevalent in Egypt. Assuit Vet Med J., 22: 160-163.

Samaha H, Mohamed TR, Khoudair RM, Ashour HM (2009). Sero-diagnosis of brucellosis in cattle and humans in Egypt. Immunobiology, 214(3): 223-226.
Samaha H, Al-Rowaily M, Khoudair RM, Ashour HM (2008). Multicenter study of Brucellosis in Egypt. Emerg Infect Dis., 14(12): 1916-1918.

Sayour AE, Azzam RA (2014). Epidemiological characterization and pathogenicity of prevalent Brucella strains in Egypt. Annals Vet Anim Sci., 77-85.

Schurig GG, Roop R M, Bagchi T, Boyle S, Buhrman D, Sriranganathan $\mathbf{N}$ (1991). Biological properties of RB51; a stable rough strain of Brucella abortus. Vet Microbiol., 28: 171-88.

Seleem MN, Boyle SM, Sriranganathan N (2010). Brucellosis: A re-emerging zoonosis. Veterinary microbiology. 140: 392- 398.

http://dx.doi.org/10.1016/j.vetmic.2009.06.021

Tuon FF, Gondolfo RB, Cerchiari N (2017). Human to human transmission of Brucella-A systematic review. Trop Med Int Health, 22: 539-546.

Ulu-Kilic A, Metan G, Alp E (2013). Clinical presentations and diagnosis of brucellosis. Recent Pat Antiinfect Drug Discov., 8: 34-41.

Verger JM, B Garin Bastuji, M Grayon, AM Mahe (1989). Brucella melitensis infection in cattle in France. Ann Rech Vet., 20:93-102.

Vicente AF, Antunes JM, Lara GH, Mioni MS, Allendorf SD, Peres MG, Appolinario CM, Listoni FJ, Ribeiro MG, Megid J (2014). Evaluation of three formulations of culture media for isolation of Brucella spp. regarding their ability to inhibit the growth of contaminating organisms. Biomed Res Int. 2014: 3.

Wareth G, Hikal A, Refai M, Melzer F, Roesler U, Neubauer H (2014). Animal brucellosis in Egypt. J Infect Dev Ctries., 8: 1365-1373.

Yaeger MJ, Holler LD. (2007). Bacterial causes of bovine infertility and abortion. In: Robert S. Youngquist WRT, editors. Current therapy in large animal theriogenology. St. Louis, MO: Elsevier, 389-99.

How to cite this article: Hosein HI, Hamdy MER, Zaitoun AMA, Menshawy AM, Rouby SR, Madkour BS, Mazeed AM, Abdel-Ra'ouf AM. Brucella prevalent strains circulating in Egypt during 2020-2021: Bacteriological and molecular study. J Vet Med Res., 2021; 28(1): 12-20. https://doi.org/10.21608/jvmr.2021.88953.1040 